\title{
o café no brasil: produção e mercado mundial na primeira metade do século $\mathbf{x x}^{\star}$ the coffee in brazil: production and world market in the first half of the $20^{\text {th }}$ century
}

\author{
Rogério Naques Faleiros $\star \star$ \\ Departamento de Economia, Universidade Federal do Espírito Santo,Vitória, Espírito Santo, Brasil \\ Pedro Geraldo Saadi Tosi $\star \star \star$ \\ Departamento de Educação, Ciências Sociais e Políticas Públicas, Faculdade de Ciências Humanas \\ e Sociais, Universidade Estadual Paulista "Júlio de Mesquita Filho”, Franca, São Paulo, Brasil
}

\section{RESUMO}

O objetivo deste artigo é apresentar uma interpretação acerca dos poderes hegemônicos em ação no comércio mundial de café na primeira metade do século XX, considerando as políticas de defesa adotadas pelo maior produtor (Brasil), a construção de produtores concorrentes e o delicado cenário caracterizado por guerras e pela crise econômica mundial. Destacam-se, no conjunto de informações apresentadas, os principais produtores de café no continente americano e no mundo, os principais portos de embarque no Brasil, bem como os principais destinos das sacas exportadas. Utilizamos como fonte o Anuário Estatístico para o ano de 1948, publicado pela Secretaria da Fazenda do Estado de São Paulo, Brasil, entre outras obras de apoio sobre as condições de comercialização do produto em escala mundial e trabalhos recentes que versaram sobre o tema, desenvolvidos em programas de pós-graduação.

Palavras-chave: Café. Brasil. Estados Unidos. Colômbia. Mercado mundial.

\begin{abstract}
The objective of this article is to present an interpretation about the hegemonic powers in action in the world coffee trade in the first half of the 20th century, considering the defense policies adopted by the largest producer (Brazil), the construction of competing producers and the delicate scenario characterized by wars and the world economic crisis. It is worth mentioning the information presented by the main coffee producers in the American continent and in the world, the main ports of shipment in Brazil, as well as the main destinations of exported sacks. We used as source the $A n$ uário Estatístico for the year 1948, published by the Secretary of Finance of the State of São Paulo, Brazil, among other support works on the conditions of commercialization of the product on a world scale and recent works that dealt with the subject, developed in postgraduate programs.
\end{abstract}

Keywords: Coffee. Brazil. United States. Colombia. World market.

* Agradecemos as críticas e sugestões encaminhadas por pareceristas anônimos da revista, que contribuíram diretamente para uma melhor elaboração deste artigo. Submetido: 1ํ de outubro de 2018; aceito: 17 de junho de 2019.

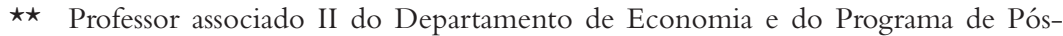
-Graduação em Política Social da Universidade Federal do Espírito Santo. E-mail: rogerio.faleiros@ufes.br

$\star \star \star$ Professor assistente doutor do Departamento de Educação, Ciências Sociais e Políticas Públicas da Faculdade de Ciências Humanas e Sociais na Universidade Estadual Paulista "Júlio de Mesquita Filho”.E-mail: pgtosi@uol.com.br 


\section{Introdução}

O mercado mundial de commodities, em especial o café, já foi objeto de estudos de diversos autores, cujas visões sobre os processos produtivos, o perfil de demanda, as estratégias de comercialização e a intervenção estatal indicam que a lei da oferta e da procura e as "vantagens comparativas" se manifestam como insuficientes à compreensão de sua dinâmica. Autores como Clarence-Smith e Topik contribuíram para o debate ao lançar luz sobre alguns fatores intervenientes e pertinentes ao controle dos preços mundiais e às mudanças dos padrões de consumo, perguntando-se, inclusive, o quão homogêneo seria essa cadeia produtiva, indicando grande segmentação de mercado (Clarence-Smith;Topik, 2003, p. 21). Esses autores, nessa obra, recolheram e organizaram hercúleo esforço de pesquisa que abarcou a produção cafeeira em diversas regiões do mundo situadas no continente africano, asiático e americano, indicando suas especificidades e estratégias às variações conjunturais desse mercado. Aliás, para os autores, o mercado mundial de café integrou-se precocemente em relação ao mercado de demais produtos.

Em outra reflexão, Topik, Marichal e Frank (2006), em esforço de pesquisa ainda mais amplo, coordenaram coletânea cujo objetivo foi o de mapear e compreender diversas cadeias produtivas e diversos mercados nos quais se inseriram a produção primária latino-americana, da prata à cocaína, indicando que, para além das análises estribadas nos Estados nacionais, típicas das teorias do sistema-mundo, a concepção das Global Commodity Chains ${ }^{1}$, centrada na produção de bens, comercialização, distribuição e financiamento, contribui mais decisivamente para a compreensão da dinâmica da produção e da comercialização. A partir dessa concepção, os autores visavam desafiar as teorias da dependência (P. Baran, Wallerstein e a própria deterioração dos termos de troca à

1 Joaquín Pinto assim descreve a abordagem de Topik, Marichal e Frank: "Essas abordagens permitem aos trabalhos (como proposto nas conclusões pelos coordenadores) estabelecer um equilíbrio entre uma visão dependente, que acrescenta um papel de vitimização às economias latinas, prisioneiras da livre decisão do ambiente externo, e a abordagem ortodoxa, que apresenta um desenvolvimento do mercado como um fenômeno social neutro, no qual as leis de oferta e demanda atuam de maneira quase autônoma sobre os cenários de troca. [...] um primeiro aspecto refere-se à falsa ideia de conceder aos países que produzem matérias-primas um papel passivo em relação à determinação de padrões de consumo e preços” (Pinto, 2018, p. 2). 
CEPAL, por exemplo), que enxergam essa produção primária da América Latina e do Caribe como reflexa exclusivamente dos mercados internacionais (Topik; Marichal; Frank, 2006), indicando que histórias e culturas locais precisam ser incorporadas à reflexão das grandes cadeias comerciais. Em capítulo da obra que versa sobre a cadeia produtiva do café, Topik e Samper indicam o protagonismo brasileiro ao transformar as pautas de consumo desse produto através de importante crescimento da oferta, o que provocou a queda dos preços e permitiu maior acesso à bebida de setores populares dos países compradores, sendo os produtores capazes de fixar preços e criar instituições comerciais encarregadas de sua distribuição, o que ocorreu também na Costa Rica (Topik; Samper, 2006, p. 121), transitando essa capacidade, paulatinamente, aos conglomerados multinacionais integrados verticalmente.

Pires sintetiza as contribuições da abordagem acima descrita, baseadas nas Global Commodity Chains, indicando que tomam o produto primário como eixo de análise, buscando mapear as redes de comercialização (interna e externa), a distribuição nos países importadores e o próprio consumidor final, conformando-os em elos de uma cadeia que se torna um objeto em si mesmo, uma totalidade a ser investigada em suas partes constitutivas e determinações recíprocas (Pires, 2007, p. 128). Pires indica também que tal visão implica a supressão do Estado nacional como totalidade explicativa, sendo os processos de interação entre os universos micro (aquele da produção realizada em âmbito local e regional) e macro (o próprio mercado internacional e os países importadores), com os componentes da intermediação comercial desde a exportação até o consumo final, processos que ocorrem acima e abaixo do âmbito dos Estados nacionais (Pires, 2007, p. 129).

Mesmo reconhecendo as contribuições transdisciplinares ofertadas por essa abordagem, buscaremos acrescentar ao debate a análise do mercado cafeeiro mundial e a relevância da produção brasileira na primeira metade do século XX, a partir das perspectivas de Arrighi (1996), em especial dos Ciclos Sistêmicos de Acumulação e de Transição Hegemônica ${ }^{2}$, uma vez que assumiremos neste artigo que o contexto ora

2 "A ideia braudeliana das expansões financeiras como fases finais dos grandes desenvolvimentos capitalistas me permitiu decompor a duração completa do sistema capitalista mundial (a longue durée de Braudel) em unidades de análise mais manejáveis, que chamei de ciclos sistêmicos de acumulação." (Arrighi, 1996, p. xi) Caracterizados 
tratado se caracteriza por intensas rivalidades interestatais e por disputas pela dominância no mercado cafeeiro entre a Inglaterra, a Alemanha, os Estados Unidos e, em menor medida, a França, buscando redefinir hierarquias.

Assumimos como hipótese que essas disputas interestatais ocorreram em momento de queda da hegemonia da Inglaterra e do padrão-ouro (em que pese seu poder financeiro nos países produtores de café até a Crise de 1929) e de ascensão da hegemonia americana, que buscava esvaziar os esquemas de defesa do café que penalizavam os consumidores americanos. Assim, para a percepção dessa problemática, as teorias do sistema-mundo, aqui representadas por esse autor, podem contribuir à reflexão.

Feito esse enquadramento teórico, o objetivo deste artigo é apresentar uma interpretação acerca dos poderes hegemônicos em ação no comércio mundial de café na primeira metade do século XX, considerando as políticas de defesa adotadas pelo maior produtor (Brasil), a construção de produtores concorrentes e o delicado cenário caracterizado por guerras e pela crise econômica mundial. Destacam-se, no conjunto de informações apresentadas, os principais produtores de café no continente americano e no mundo, os principais portos de embarque no Brasil, bem como os principais destinos das sacas exportadas. Utilizamos como fonte o Anuário Estatístico para o ano de 1948, publicado pela Secretaria da Fazenda do Estado de São Paulo, Brasil, entre outras obras de apoio sobre as condições de comercialização do produto em escala mundial e trabalhos recentes que versaram sobre o tema, desenvolvidos em programas de pós-graduação.

pela dominância de um eixo de poder político e econômico, esses ciclos desenvolveriam, de maneira expansiva e não linear, fases de expansão produtiva seguidas pela expansão financeira, que já acusaria a crise sinalizadora de determinada hegemonia e a emergência de novo ciclo produtivo, sediado em outro circuito político e econômico, geralmente mais amplo e complexo do que o anterior.A periodização deste artigo busca compreender o momento do capitalismo histórico no qual observamos justamente a transição de um ciclo sistêmico de acumulação a outro, no caso, a transição hegemônica desde a Inglaterra até os Estados Unidos, e as condicionalidades impostas ao mercado cafeeiro à época. 


\section{O Brasil, síntese das intervenções e o mercado cafeeiro mundial}

Durante a primeira metade do século XX, o Brasil respondeu, seguramente, por mais da metade da oferta mundial de café, registrando-se em alguns períodos proporções muito superiores, o que colocava o país no centro de qualquer estratégia comercial monopólica nesse mercado em nível mundial.Tais estratégias passavam pelas políticas de valorização dos grãos, por toda a logística de embarques e de distribuição em nível mundial, bem como a crescente concorrência com os demais países produtores, notadamente a Colômbia. Na outra ponta, os Estados Unidos respondiam por cerca de 70\% do consumo mundial na década de 1940 .

Embora os estados brasileiros de São Paulo, do Rio de Janeiro e de Minas Gerais comandassem a produção nacional em termos de volume, qualidade, logística e força política, outros estados também alcançavam alguma produção na primeira metade do século XX, mesmo que, evidentemente, em volume muito menor.

Ainda que o café possa ser definido como uma commodity, verificamos nesse negócio um mercado bastante segmentado, envolvendo grãos de distintas qualidades e procedências, tornando o mercado cafeeiro um verdadeiro emaranhado de enigmas, blends e padrões de consumo. Isso se deve ao fato de a bebida verdadeiramente "atravessar" as hierarquias sociais em diversas partes do mundo, sendo consumida desde as altas rodas de Manhattan até o chão de fábrica em São Paulo. Inicialmente, até meados do século XIX, a bebida era apreciada nos bistrôs de Paris como posicionada sobremesa, entrementes, com o advento da Segunda Revolução Industrial, passou a figurar recorrentemente na cesta de consumo dos trabalhadores das fábricas ${ }^{3}$. Por isso, compreender o mercado cafeeiro em sua totalidade exige um acurado exame de procedências e domínio sobre as informações; ademais, envolve também o poder

3 Contudo, deve-se destacar que, mesmo antes da Guerra de Secessão em 1860, a bebida já era conhecida e apreciada na América do Norte por obra, sobretudo, dos irmãos Arbuckles (John e Charles). Os famosos pacotes de "ARIOSA" (acróstico de Arbuckle, Rio e Santos, dado operar com cafés oriundos desses portos), distribuídos a partir de Pittsburgh e depois Boston. Empresas e comerciantes como Chase \& Sanborn (que operavam com cafés javaneses), James Folger, Jabez Burns, O. Havemeyer e Hermann Sielcken já manejavam volumes consideráveis de café em fins do século XIX (Pendergrast, 2002, p. 72). 
de construir e convencionar uma "qualidade", dado que esse fator envolve uma série de esforços de propaganda ${ }^{4}$, paladares e preferências. Em geral, no Brasil, os cafés do Oeste Paulista e do Sul de Minas eram vistos como de melhor classificação, ordinariamente o Tipo 4, ao passo que a produção da chamada Zona da Mata mineira, do Rio de Janeiro e do Espírito Santo era classificada como Tipo 7, as mais baixas da escala então utilizada ${ }^{5}$.

É certo que as casas comissárias e os grandes exportadores consolidavam/destruíam reputações pelo mundo afora na constante disputa pela qualidade que envolvia o poder público num esforço de propaganda, difusão técnica, lobby e pesquisa científica. Em outra oportunidade demonstramos, por exemplo, a luta do estado do Espírito Santo na década de 1920 para "livrar-se" da classificação de seus grãos efetuada no Rio de Janeiro (Tosi; Faleiros, 2017, p. 174), o que envolveu pesquisa científica, o estabelecimento de uma Bolsa Oficial do Café naquele estado, a construção de um porto e de armazéns reguladores para controle da oferta ${ }^{6}$.

Assim, embora ocupasse posição quase monopólica no mercado cafeeiro, a produção brasileira foi paulatinamente enfrentando a concorrência colombiana nos mercados de elevada qualidade, especializando-se numa faixa mais ordinária de consumo. Isso não necessariamente

4 A título de exemplificação, a União e os diversos poderes subnacionais lavraram contratos de propaganda no exterior, na década de 1920: a Agência Havas para a propaganda na França, Argélia,Tunísia e em Marrocos; a Cia. Franco-Brasileira em Paris; a Saravano Braga \& Cia. na Grécia, Bulgária, Iugoslávia, Turquia e no Egito; a Theodor Wille \& Cia. na Alemanha e Suíça; a Centrokomise na Tchecoslováquia; a Linha Norueguesa Sul-Americana na Noruega; e a S/A Café Paulista nos países do Prata, como também a Jacob Guyer e Ageo Ferreira Camargo.

5 A classificação utilizada na primeira metade do século XX no Brasil era a seguinte: (1) Alta Mogiana e Sul de Minas; (2) São Paulo-Goiás, Ararquarense, Douraense; (3) Paulista e Bragantina; (4) Alta Paulista e Noroeste; (5) Sorocabana; (6) Central do Brasil (São Paulo e Rio) e Zona da Mata (Minas); (7) Espírito Santo (TipoVitória) (Graner; Godoy Jr., 1967, p. 299).

6 Como consequência foi encontrada a recorrência de cafés Tipo 4 em Itaguaçu, Viana, Santa Teresa, Muniz Freie e Pau Grande, municípios daquele estado, sendo esses cafés ordinariamente classificados como Tipo 7 (Vitória) nos portos fluminenses, o que impunha maiores dificuldades de embarque, dado que no contexto da chamada Defesa Permanente, na década de 1920, os cafés de pior qualidade eram mais duramente penalizados, ampliando o tempo de estocagem e o correlato custo operacional. 
implicava menores lucros para os operadores dos cafés brasileiros, dado o volume superior de negociações e o fato de que cafés de pior qualidade possuem ampla aceitação nos mercados e na formação de estoques, devido ao potencial para a elaboração de blends.

Feita essa breve caracterização do mercado cafeeiro no Brasil e em nível mundial, marcada pela segmentação e pelas especificidades regionais, passemos agora ao exame das condicionantes gerais (intervenções) do mercado cafeeiro a partir dos maiores ofertantes (Brasil e Colômbia) e, na sequência, dos principais fluxos mercantis da rubiácea a partir do maior produtor.Após, teceremos algumas considerações finais, buscando sistematizar as principais estratégias de disputas pelo mercado cafeeiro e pelos seus circuitos.

Em função da relativa inelasticidade-preço, típica do perfil de demanda do café, um elemento de fundamental observação nesse mercado, dentro da periodização que vamos tratar (1915-1947), o que, aliás, consiste em nosso critério de periodização, é o fato de que o setor cafeeiro operou sob seguidas intervenções caracterizadas por convênios entre o governo brasileiro (maior produtor) e o sistema bancário internacional coadunados com os principais players desse negócio. A primeira experiência de sustentação dos preços - defesa - ocorreu no âmbito do Convênio de Taubaté, tocado por São Paulo a partir de 1906 e arquitetado por Sielcken no sentido de formação de um consórcio que regularia os estoques forçando a alta dos preços ${ }^{7}$. O convênio praticamente colocava a produção nacional à mercê dos ganhos variáveis dos exportadores de grosso calibre, significando também aumento de preço para o consumo final desse bem no mercado norte-americano.

Uma segunda experiência foi a defesa elaborada entre 1917-1918. Segundo Delfim Netto, a intervenção do estado de São Paulo foi feita em virtude da safra 1917-1918, que se apresentava relativamente volumosa, atingindo 15 milhões de sacas, quando o consumo, por causa da Primeira Guerra Mundial, havia caído abaixo desse nível. Os mecanismos de defesa foram facilitados pela geada de 1918, que reduziu a produtividade

7 Juntamente com bancos alemães e britânicos comerciantes de café, Sielcken organizou a compra de café em Santos a um preço médio de 7 centavos de libra, bancando $80 \%$ desse valor e cabendo $20 \%$ ao governo de São Paulo (avalizado pela União a partir de 1907). Com alguns ajustes, o plano já havia sido vislumbrado por Alexandre Siciliano em 1903 (Pendergrast, 2002, p. 101; Saes, 1997, p. 59). 
dos cafeeiros, tornando a oferta brasileira muito inferior à normal. Nessas circunstâncias, era inteiramente natural que a procura, principalmente dos especuladores, se precipitasse, o que elevou os preços do Rio 7 de 10,7 centavos/libra-peso para 17,3 centavos/libra-peso em dezembro do mesmo ano, que, depois de uma ligeira baixa, atingiu 22,8 centavos/libra-peso em julho de 1919 (Delfim Netto, 1979, p. 70).

O que se pode dizer desta situação é que o estado de São Paulo, comprando café (compras efetuadas por emissões de papel-moeda), impediu que os preços em moeda nacional caíssem a níveis ainda mais baixos e que, agindo como agiria um especulador normal, usufruiu os beneficios de um movimento favorável de mercado ${ }^{8}$.

Embora o autor possua positiva avaliação dos resultados das intervenções no mercado cafeeiro realizadas antes de 1920, ressalta que a ausência de restrições à oferta paulatinamente solapava a racionalidade dessa ação?.

Já a valorização de 1921-1924 contava com dois aspectos inversamente colocados no programa de valorização anterior; agora a inflação mundial liquidou-se numa crise de importantes proporções e o volume de produção apresentou-se acrescido. Ainda segundo Delfim Netto, a depressão que se seguiu à prosperidade do pós-guerra nos Estados Unidos foi curta e severa. A crise se agravou ainda mais quando o Federal Reserve reduziu o crédito habitual fornecido às grandes casas importadoras. Assim, era justamente a queda do preço o fator que caracterizava essa crise e prontamente a intervenção federal se fez presente, so-

8 A saca de café atingiu o preço de $47 \$ 390$ em 1918, $94 \$ 612$ em 1919 e $74 \$ 703$ em 1920. Além da diminuição da oferta e do aumento da procura, a ascensão dos preços se explica pela grande inflação mundial ocorrida durante a guerra e pela pressão inflacionária interna, dado o aumento das emissões (Delfim Netto, 1979, p. 72).

9 Ainda que a queda dos preços se manifestasse, os cafeicultores, dentro de uma racionalidade específica a essa atividade, insistiam em novos plantios, mantendo a fronteira agrícola em constante movimento. Tal racionalidade deriva de três fatores: (1) da compensação da queda de produtividade nas lavouras mais antigas com novos plantios nas zonas de expansão; (2) em parte do próprio movimento dos preços internacionais; (3) da própria manutenção e coesão da força de trabalho disponível nas fazendas, sempre ávida por novas lavouras com vistas à ampliação de seu acesso a terra, de modo que os mecanismos de rebaixamento dos salários monetários dos trabalhadores do café persistiram no tempo e no espaço (Faleiros, 2010, p. 463 e ss.). 
bretudo por dois fatores: o sucesso das intervenções anteriores e a doutrina que consagrava o café como um problema nacional. Nas palavras do presidente Epitácio Pessoa, “o café representa a principal parcela no valor global de nossa exportação e é, portanto, um problema nacional, cuja solução se impõe à boa política econômica e financeira do Brasil" ${ }^{10}$. Para além da influência exercida no poder pelo grande capital cafeeiro, Maria Sylvia Macchione Saes nos lembra de que as intervenções eram positivas também para o governo, pois

a preocupação real dos formuladores da política econômica federal durante a República Velha era com o valor externo da moeda. Eles apoiaram a defesa paulista somente na medida em que perceberam que a intervenção direta no mercado de café era um complemento essencial para seu objetivo principal de equilibrar as contas externas. (Saes, 1997, p. 66)

Utilizando-se como garantia o café adquirido, levantou-se um empréstimo externo de 9 milhões de libras esterlinas em 1921, cuja finalidade era a paulatina liquidação dos estoques. Mais uma vez as condições de produção auxiliaram uma liquidação bem sucedida da operação, pois as safras de 1921-1922 e 1922-1923 foram das menores de que se tinha notícia desde o começo do século, e o estoque mundial do produto que havia atingido 10 milhões de sacas em julho de 1919, caiu para 5,3 milhões no mesmo mês de 1923.

O ano de 1924 constitui marco estratégico na política nacional de defesa do café. No plano federal, por indicação da Missão Montagu ${ }^{11}$, adotou-se uma política monetária extremamente restritiva, cujo objetivo era a valorização cambial simultaneamente à renúncia à responsabilidade pela gestão do programa de defesa permanente da produção nacional estabelecido, como vimos, em 1922, e que onerava sobrema-

10 Delfim Netto (1979, p. 78).

11 Tratava-se de uma missão de peritos financeiros liderada por Edwin Samuel Montagu, cujo objetivo principal era promover um estudo sobre a situação financeira e fiscal do Brasil com vistas a avalizar (ou não) um empréstimo pretendido com os Rothschild. Além de Montagu, compunham a missão Charles Addis, diretor do Banco da Inglaterra e presidente do Hong Kong and Shangai Bank; Lord Lovat, homem com vultosos interesses em terras e plantações de algodão; Hartley Withers, antigo editor de The Economist; e Sir Willian McLintock, sócio de uma das maiores firmas inglesas de contabilidade e auditoria. Sir Henry Lynch, representante permanente dos Rothschild no Rio de Janeiro, também acompanharia a missão (Fritsch, 1980, p. 723). 
neira a Carteira de Redesconto do Banco do Brasil. A simultaneidade dessas ações indica, na perspectiva do governo federal liderado pelo mineiro Arthur Bernardes, o primado dos objetivos de revalorização-estabilização cambial sobre a política de sustentação dos preços, deixando-a a cabo dos governos estaduais. Em verdade, a participação do governo federal na defesa do café, doravante, se daria pela manutenção de finanças equilibradas e de uma taxa de câmbio valorizada e confiável, o que seria fundamental para o financiamento das defesas estaduais, todas elas amparadas em recursos externos.

Pela Lei n. 2.004, de 19 de dezembro de 1924, o estado de São Paulo assumiu o protagonismo do mecanismo de defesa do café, criando-se o Instituto Paulista de Defesa do Café, que se encarregou da execução de um vasto plano de defesa que se apoiaria na

1) regularização das entradas de café no Porto de Santos;

2) na realização de empréstimos a juros "módicos";

3) na compra de café sempre que isso fosse julgado necessário para a regularização da oferta.

Previa a mesma lei a criação do Banco Paulista de Crédito Agrícola, o que de fato não ocorreu, já que o capital do Banco de Crédito Hipotecário e Agrícola do Estado de São Paulo teve o seu capital aumentado em 20.000\$000 e passou a chamar-se Banco do Estado de São Paulo (1926), sendo este o banco responsável pela sustentação do sistema de "warrantagem": fornecimento de empréstimos para os produtores de até $60 \$ 000$ por saca retida nos armazéns reguladores. O fundo de capital do instituto (o fundo da Defesa Permanente) foi composto pelos recursos advindos de um empréstimo de 10 milhões de libras esterlinas no banco Lazard Brothers, tendo-se como garantia uma taxa de viação de $1 \$ 000$ ouro sobre cada saca de café transportada no estado e o próprio governo paulista para efeitos de garantia colateral. O Instituto do Café do Estado de São Paulo, assim chamado a partir de 1926, celebrou convênios com os demais estados produtores com vistas à ampliação, também nessas unidades da Federação, da defesa do café, o que passava pelo estabelecimento da taxa de viação, pela propaganda e pela melhoria técnica da produção ${ }^{12}$.

12 Conforme salientaram Kenwood e Lougheed, vários países especializados na produção de produtos primários colocaram em prática algum tipo de intervenção nos 
Em novembro de 1925, ocorreu o primeiro convênio entre os estados de São Paulo e Minas Gerais, com vistas a regularizar os embarques de café nas várias estradas de ferro comuns a esses estados, e já em maio de 1927 ocorreu o chamado segundo convênio, agora se ampliando o acordo com a participação do Rio de Janeiro e do Espírito Santo e firmando-se o compromisso da defesa conjunta. Nos termos desse acordo, o controle das entradas seria estendido a todos os portos, fixando-se o estoque máximo e a participação de produção de cada estado. A ideia era permitir a remessa para o porto de acordo com as exportações do mês anterior, sendo que as entradas diárias em cada um deles, no mês corrente, eram fixadas dividindo-se por 25 o volume exportado no mês anterior (Delfim Netto, 1979, p. 94). Nesse convênio, em termos de participação nas cotas de café nos portos de exportação, foi definido:

a. No Rio de Janeiro o limite era de 360.000 sacas/mês: 55,75\% para Minas Gerais, 30\% para o Rio de Janeiro, $11,75 \%$ para o Espírito Santo e 2,5\% para São Paulo;

b. Em Santos o limite era de 1.200.000 sacas/mês: 89\% para São Paulo e 11\% para Minas Gerais;

c. Em Paranaguá o limite era de 50.000 sacas/mês a partir de 1928: 100\% para o Paraná;

d. Em Vitória o limite era de 150.000 sacas/mês: 73,3\% para o Espírito Santo e 26,7\% para Minas Gerais. (Faleiros; Nunes, 2016, p. 165-166)

Grosso modo, a chamada Defesa Permanente, com pequenos ajustes e conflitos federativos crescentes, vigorou até a crise. Em 1929 o preço

mercados visando defender-se de variações de preços no período em tela, caracterizado por instabilidades e pela derrocada final do padrão-ouro: "Ao mesmo tempo em que houve variações importantes nos movimentos de preços de todos os itens, dos quais alguns subiram e outros caíram ou permaneceram estacionários, a queda foi quase geral nas matérias-primas, embora, no caso de certos alimentos, como açúcar e trigo, os preços também caíram acentuadamente. Mas, mesmo quando as quedas se seguiram relevantes, os preços não refletiam as mudanças que realmente ocorreram no condições de mercado, uma vez que a venda desses produtos primários estava sujeita a condições monopolistas, à mercê das quais os preços eram frequentemente mais altos do que se teria se formado em condições de perfeita concorrência. Daí a existência de planos de controle de preços, por vários períodos na década de 1920, para produtos como borracha, café, açúcar, trigo e cobre" (Kenwood; Lougheed, 1995, p. 275). 
da saca de café ficou muito suscetível a uma pressão baixista, dada a espetacular florada dos cafezais brasileiros, que anunciavam uma gigantesca produtividade para o ano agrícola de 1928-1929. Os preços foram sustentados, porém, com a violenta crise e os bancos americanos restringiram a concessão de crédito e reduziram suas operações sobre café, procurando elevar sua liquidez. Com a recusa do Banco do Brasil em financiar as compras, a situação tornou-se insustentável e o preço do café Santos Tipo 4 caiu de 22,4 centavos por libra-peso em setembro para 15,2 centavos por libra-peso em dezembro, e 14,1 centavos por libra-peso no primeiro semestre de 1930 e 12,0 centavos por libra-peso no segundo semestre do mesmo ano (Delfim Netto, 1979, p. 97).

A aposta de Washington Luiz, então presidente brasileiro, pautou-se por uma drástica mudança de posição. Até então ardoroso defensor da defesa, ele temia que uma estrondosa desvalorização da moeda prejudicasse seus interesses políticos num ano de eleições, e, confiando que uma baixa dos preços pudesse provocar uma grande expansão da exportação, aumentando-se assim a receita de cambiais, o que salvaria o trabalho de quatro anos em cima da estabilização cambial, abandonou o Instituto do Café (visão não totalmente descabida, pois em outras circunstâncias provavelmente isso ocorreria, já que os operadores procurariam refazer estoques para enfrentar posteriormente o mecanismo de defesa). O "erro" dessa aposta estava numa clara subestimação da crise ${ }^{13}$.

Em instigante artigo, Hynes, Jacks e O'Rourke discutem a desintegração do comércio mundial de commodities no período entreguerras. Com especial atenção ao período da Grande Depressão, indicam que, para além da redução das inversões e da Lei Smoot-Hawley (que restringia as importações), operam no contexto outras variáveis, tais como as mudanças nas políticas comerciais, o colapso do padrão-ouro (à Eichengreem) e a "evaporação" do crédito comercial, e as fricções protecionistas típicas de momentos de crise (Hynes; Jacks; O’Rourke, 2012, p. 121). Os

13 Fritsch (1988) discorda da afirmação deVillela e Suzigan (2001), baseada em Peláez (1971) de que a ruptura do mercado de café ocorrida em outubro de 1929 não foi somente devida à superprodução induzida pelas operações da política de defesa dos preços do café. Ele afirma que essa posição é "profundamente simplista" porque desconsidera mudanças cruciais nas condições de crédito que ocorreram nesse ano, tanto no Brasil quanto nos mercados de capitais internacionais. Isso, aliado à "deserção" do governo federal, afetou seriamente a indústria do café e a posição do balanço de pagamentos do país (Bacha; Greenhill, 1992, p. 57). 
autores indicam um "espetacular" declínio do comércio mundial na década de 1930 e um aumento dos custos comerciais (sobretudo com os Estados Unidos) em função do protecionismo; contudo, apontam que o aumento desses custos, embora relevante, deve estar atrelado a outros fatores explicativos, como o escasseamento do crédito comercial (Hynes; Jacks; O’Rourke, 2012, p. 141). Considerando o café bem de demanda inelástica e a ausência de substitutos perfeitos, torna-se dificil imaginar que a crise tenha afetado o Brasil pelo lado da demanda, sendo mais plausível a hipótese de que, com a debacle mundial, o Brasil perdera as condições de gerir os estoques, aspecto aparentemente não considerado pelos governantes à época.

Entre 1931 e 1933, conforme destacou Saes, tem-se um período de transição na condução da política cafeeira. Em 1931 foi criado o Conselho Nacional do Café (CNC), que em 1933 foi substituído pelo Departamento Nacional do Café (DNC), autarquia federal subordinada ao Ministério da Fazenda. O objetivo básico das políticas, nesse período, era a redução da oferta de café, que foi obtida, principalmente, por meio de cotas de exportação para a retenção e o sacrificio, e até 1937 a política cafeeira continuou desempenhando um importante papel na sustentação desse setor, retirando os excedentes do mercado e promovendo o "Reajustamento Econômico". Entretanto houve, por parte do Estado, um esforço inequívoco para limitar sua participação. Ainda conforme Saes,

em fins de 1937, a pressão praticamente unânime do setor privado cafeeiro, aliada à escassez de divisas, forçou a reorientação da política cafeeira. Abandonou-se parcialmente a sustentação de preços, adotando um dumping internacional do café, na tentativa de obrigar os concorrentes a negociar um acordo internacional. (Saes, 1997, p. 72)

A partir de 1937, não seria concedido nenhum estímulo ao setor cafeeiro além do indispensável para impedir sua ruína e defender a capacidade para importar, que, mesmo estagnada, era a única garantia de possibilidade de continuidade do processo de industrialização, como veremos a seguir. Nesse período, dados os altos estoques do produto, os preços internacionais do café não reagiram, permanecendo em torno de 8 centavos por libra-peso, 60\% abaixo do preço de 1929 (Aureliano, 1999, p. 135). As sempre desanimadoras receitas de exportação do café 
Gráfico 1 - Principais produtores de café no continente americano (1915-1947)

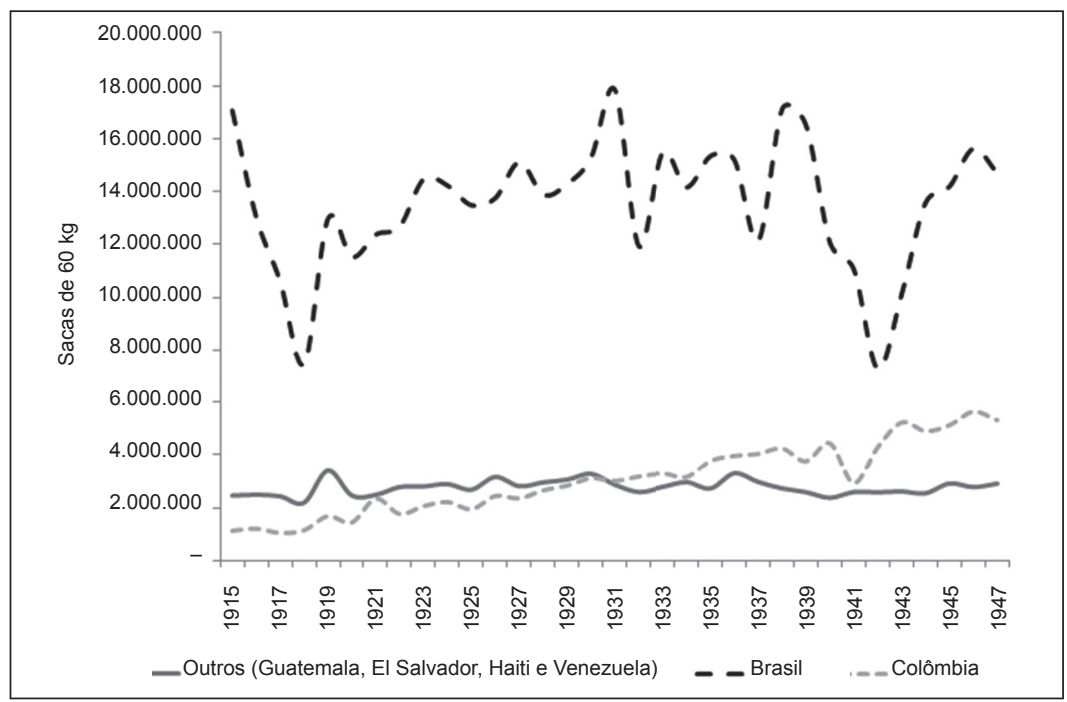

Fonte: Anuário Estatístico (1948, p. 137-150).

e as dificuldades cambiais que se verificavam levaram o governo brasileiro a tentar a todo custo a diversificação de exportações e de mercados. A orientação era de reduzir ao mínimo a sustentação do café, concepção que atinge seu auge em 1937, quando se estabeleceu a chamada "política de concorrência". A ideia era deixar o café chegar normalmente aos portos de embarque livre de impostos, e, como consequência, em 1938 os preços caíram em torno de $25 \%$ e houve um aumento de $40 \%$ nas exportações (certamente em função do aumento dos estoques internacionais, aproveitando-se da queda dos preços). Mas a deflagração da Segunda Guerra Mundial, com o fechamento dos mercados europeus, trouxe novas dificuldades à cafeicultura.

De 1931 a 1944, cerca de 78 milhões de sacas de café tinham sido destruídas (Saes, 1997, p. 72), verificando-se relativa subprodução; em 1944 o Departamento Nacional do Café já sofria claras pressões no sentido de sua extinção, o que ocorre derradeiramente em 1946. A partir de 1941, os Estados Unidos passaram a responder por cerca de $90 \%$ das exportações brasileiras, caindo para $75 \%$ após o final da guerra ${ }^{14}$.Também em 1941 Roosevelt ratificou o Acordo Interamericano do Café, estabe-

14 Anuário Estatístico (1948, p. 88). 


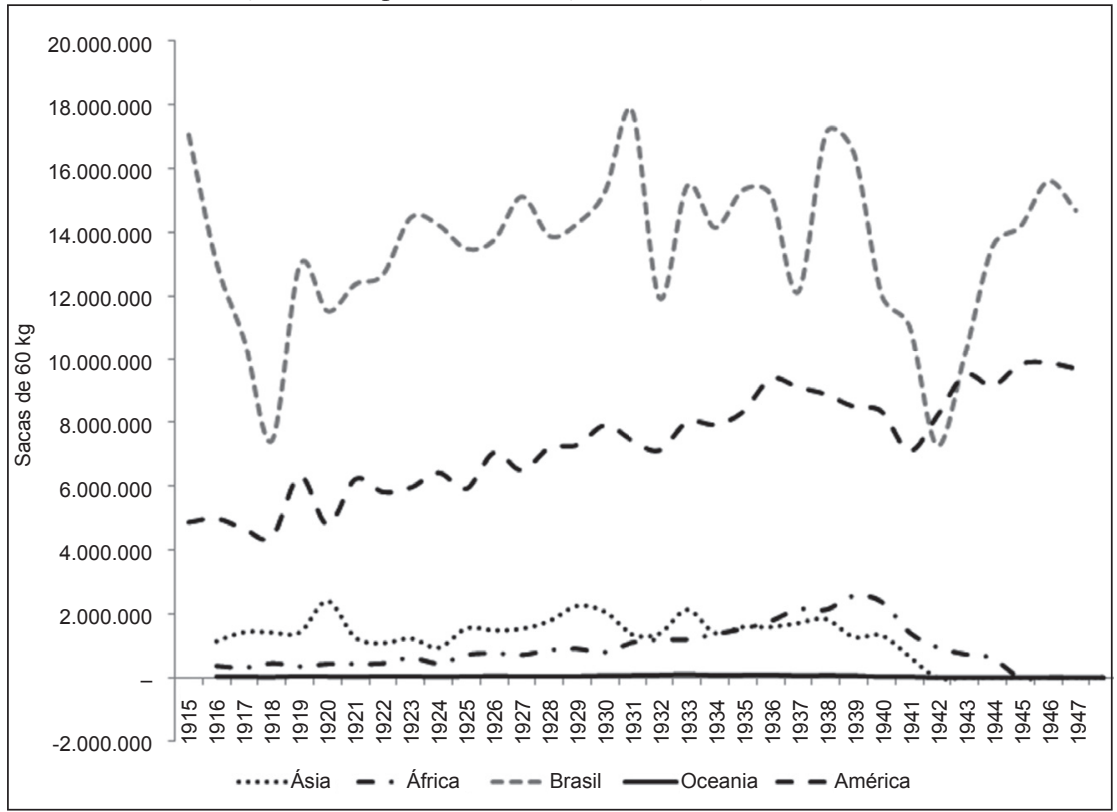

Fonte: Anuário Estatístico (1948, p. 137).

lecendo cotas de exportação para o típico monopsônio americano durante a guerra. Em 1946 as cotas caíram em desuso com o fim dos controles sobre o mercado cafeeiro (CPDOC, s.d.).

É nesse contexto de políticas de intervenção ocorridas pelo lado do maior ofertante (Brasil) que descreveremos agora os principais fluxos de comércio do café em escala mundial. Essa reconstituição fez-se necessária pelo fato de que entre 1915 e 1947 o Brasil produziu, com folga, mais de $60 \%$ do café das Américas embarcado nos portos mundiais exclusive 1937 e 1944 - (Anuário Estatístico, 1948, p. 137), salientando que esse continente, no período, respondia, em média, a 94\% da oferta mundial. Abaixo, podemos visualizar os maiores produtores americanos entre 1915 e 1947. O conjunto de produtores americanos inclui, além do Brasil e da Colômbia, a Venezuela, a Guatemala, El Salvador, o Haiti, o México, a Costa Rica, o Equador, Cuba, Honduras, o Peru, a Nicarágua, a República Dominicana. Para efeitos de demonstração, consideramos no Gráfico 1 os maiores produtores do continente e, na sequência, a produção por continentes no Gráfico 2, em comparação com a produ- 
ção brasileira, permitindo-nos perceber a posição desse país no cenário mundial.

\section{Habemus Colômbia}

Como segundo maior produtor de café do mundo, a dinâmica colombiana ${ }^{15}$ segue muito proximamente aquela ocorrida no maior produtor. Segundo Pérez Toro, no período compreendido entre 1910 e 1928, o café colombiano mostrou forte recuperação do nível de preços de 10 para 28 centavos de dólar americano por libra esterlina (Pérez Toro, 2013, p. 351). Ainda conforme o autor, com essa renda o país pode formular e implementar políticas de ampliação da malha ferroviária ${ }^{16}$, integração das regiões produtoras e a promoção da diversificação produtiva. Entre 1903 e 1929, as exportações colombianas de café se ampliaram de 500 mil sacas para 3 milhões de sacas e os ingressos do comércio internacional se ampliaram de 800 mil dólares para 84 milhões de dólares anuais. Como podemos observar no Gráfico 1, é justamente na década de 1920 que a Colômbia ultrapassou as exportações da soma dos demais produtores americanos (exclusive o Brasil). Com esse incremento, a produção mundial chegou a 29 milhões de sacas ao final da década de 1920.

Segundo Delfim Netto, após o Convênio de Taubaté, a sustentação dos preços internacionais deu maior segurança à expansão colombiana, agindo a defesa de 1917-1918, a de 1921 e a Defesa Permanente no mesmo sentido. Ao final da década de 1920, quase a totalidade da produção daquele país era direcionada aos Estados Unidos (Delfim Netto, 1979, p. 120). Sobretudo com a Defesa Permanente, o Brasil (ou os financistas

15 A Colômbia surgiu na segunda metade do século XIX como um país cafeeiro importante, coincidindo com uma fase de desequilíbrio crescente no mercado mundial do café. Essa expansão cafeeira foi também um processo de migração da fronteira cafeeira ao interior do país, sendo as principais regiões produtoras Cundinamarca, Norte de Santander, Santander, Antioquia (incluindo Caldas) e Valle do Cauca. No início do século XX, a produção colombiana foi duramente atingida pela Guerra dos Mil Dias, sobretudo em Cundinamarca e Santander, passando a ser Antioquia, Caldas e Manizales os principais centros cafeeiros do país (Ocampo, 1983, p. 465).

16 É o caso das novas linhas de transporte ferroviário, dos cabos aéreos em Caldas, que iam de Manizales a Mariquita, dos portos nos rios Magdalena e Caua e do estabelecimento da navegação a vapor (Pérez Toro, 2013, p. 352). 
que sustentavam a defesa, exclusivamente europeus) promoveu um ajustamento entre a oferta e a procura mundial, levando os importadores americanos a buscar quantidades crescentes de café na Colômbia, contexto no qual aquele país expandiu consideravelmente sua produção.

$\mathrm{O}$ que nunca os defensores da defesa compreenderam foi o fato de que a sustentação dos preços representava um estímulo fabuloso e um mercado inteiramente aberto para os concorrentes do Brasil; em 1922-23, a Colômbia exportou, em média, cerca de 1,8 milhão de sacas e, em 1928-29, nada menos do que 2,7 milhões. (Delfim Netto, 1979, p. 121)

Adicionalmente ao preciso diagnóstico de Delfim Netto, somam-se a expansão da fronteira agrícola após a Guerra dos Mil Dias, os massivos investimentos americanos na infraestrutura colombiana ${ }^{17}$ (sobretudo em transportes) advindos de investimentos diretos dos Estados Unidos (cerca de 88,2 milhões de dólares anuais entre 1920 e 1928) e das indenizações do canal do Panamá, assim como o próprio aumento do consumo mundial e de sua segmentação em busca de "qualidade" para paladares superiores. Há também que se considerar uma ampliada condição da cafeicultura colombiana de resistir às baixas de preços e às crises, dado que, por ser praticada em unidades produtivas de dimensões inferiores às brasileiras, facilitava o esforço de conversão/reconversão de culturas e de força de trabalho, como também pelo fato de que operava com custos fixos reduzidos.

Na década de 1930, a Federacíon Nacional de Cafeteros de Colombia, fundada em 1927, procurou construir armazéns reguladores e contribuiu para a organização da Caja de Crédito Agrário, para financiar a produção e segurar as vendas. $\mathrm{O}$ objetivo era defender o preço do Manizales, um contexto de quedas bruscas mesmo para os cafés de maior qualidade. Aproveitando o derrumbre do padrão-ouro na década de 1930 e as circunstâncias da guerra com o Peru em 1934, o governo colombiano

17 De um total de 25 milhões de dólares ingressados a título de indenizações, 3,2 milhões foram investidos na Línea Puerto Wilches-Bucaramanga; 2,4 milhões na Ferrocarril de Nariño (Tumaco-Pasto); 2 milhões na Ferrocarril del Carare; 3,2 milhões na Ferrocarril del Norte; 4,6 milhões na Ferrocarril del Pacífico (Buenaventura-Cali); 1,2 milhão na Ferrocarril de Antioquia; 0,8 milhão na Ferrocarril Caldas; 2 milhões na Ferrocarril Bolívar; 0,6 milhão na Ferrocarril der Sur; e mais 5 milhões de dólares de aporte para financiamento do Bando de la República (Pérez Toro, 2013, p. 55). 
empreendeu uma política de caráter heterodoxo, permitindo a desvalorização da moeda e aumentando as taxas de exportação, o que permitiu investimentos nas regiões cafeeiras mais deprimidas (Antioquia, Cundinamarca), mantendo os ingressos nominais em moeda nacional diante das quedas de preço internacionais (Pérez Toro, 2013, p. 353). As décadas de 1930 e 1940 inauguraram um novo paradigma para a cafeicultura colombiana caracterizada pelas intervenções (defesas) e por sua participação nos acordos internacionais do café, em detrimento da política de matriz concorrencial típica da década de 1920. A rigor, a mudança de trajetória liga-se diretamente à brutal mudança dos fluxos de capitais norte-americanos, que inverteram os seus vetores a partir da Crise de 1929 e da Grande Depressão, evidenciando a estratégia estadunidense de combate à defesa brasileira e seus apoiadores europeus (Lazard Brothers, Ítalo-Belga e outros bancos envolvidos com o financiamento da defesa permanente nos estados brasileiros produtores de café, notadamente São Paulo, Minas Gerais, Espírito Santo e Rio de Janeiro) (Faleiros; Nunes, 2016, p. 169).

Com o aporte americano em infraestrutura e certa facilidade para entrada no mercado americano, tentando furar o esquema Brasil-Europa, a produção colombiana cresceu significativamente após a Primeira Guerra Mundial: em 1920, esse país exportou 1,4 milhão de sacas e, em 1930,3,1 milhões, ao passo que o Brasil subiu de 11,5 para 15,2 milhões no mesmo período. A rigor, as exportações colombianas foram sempre crescentes no período de 1915 a 1947, salvo em alguns anos da Segunda Guerra, enquanto as exportações brasileiras apresentaram maiores flutuações cíclicas e a um custo de estocagem crescente, em função das defesas implementadas que puxaram todo o mercado. Exemplo é a debacle da Crise de 1929, momento no qual as exportações brasileiras caíram de 18 para 11 milhões de sacas entre 1931-1932, ao passo que as exportações colombianas cresceram nesse agudo momento da Grande Depressão.

Há elementos importantes a serem destacados nesse momento da análise: (1) os cafés mais bem classificados, em geral, apresentam menor flutuação cíclica, pois são os últimos a cair de preço em momentos de crise e os primeiros a se recuperar. Isso se explica pelo fato de que o segmento da sociedade no qual são consumidos (elite e classes médias altas) é menos suscetível a choques de renda que os levem a alterar sig- 
nificativamente seu padrão de consumo; (2) para além dessa característica, temos que considerar também que grãos de maior qualidade, em blends, melhoram estoques ruins ou ordinários, como o Tipo 4 (Santos), garantindo assim a sua constante colocação no mercado, sendo, portanto, prioritários na composição dos estoques; (3) a defesa brasileira, sobretudo a permanente, a partir de 1924, obstruía com maior veemência os grãos de pior classificação, dado que exerciam forte pressão sobre a produção brasileira, abrindo espaço ainda maior para o café colombiano de pior qualidade, comercializado sem nenhuma peia. Como resultado, no período considerado a participação brasileira nas exportações mundiais caiu de cerca de 70\% para 60\% entre 1915 e 1947, enquanto a colombiana cresceu de $9,7 \%$ para $22 \%$.

Como podemos observar nos gráficos abaixo, durante o período considerado, embora o volume exportado pelo Brasil fosse muito superior ao colombiano, este sempre alcançou melhores cotações na Bolsa de Nova York, corroborando as ideias acima expostas.

Gráfico 3 - Exportação e participação no mercado mundial: Brasil e Colômbia (1915-1947)

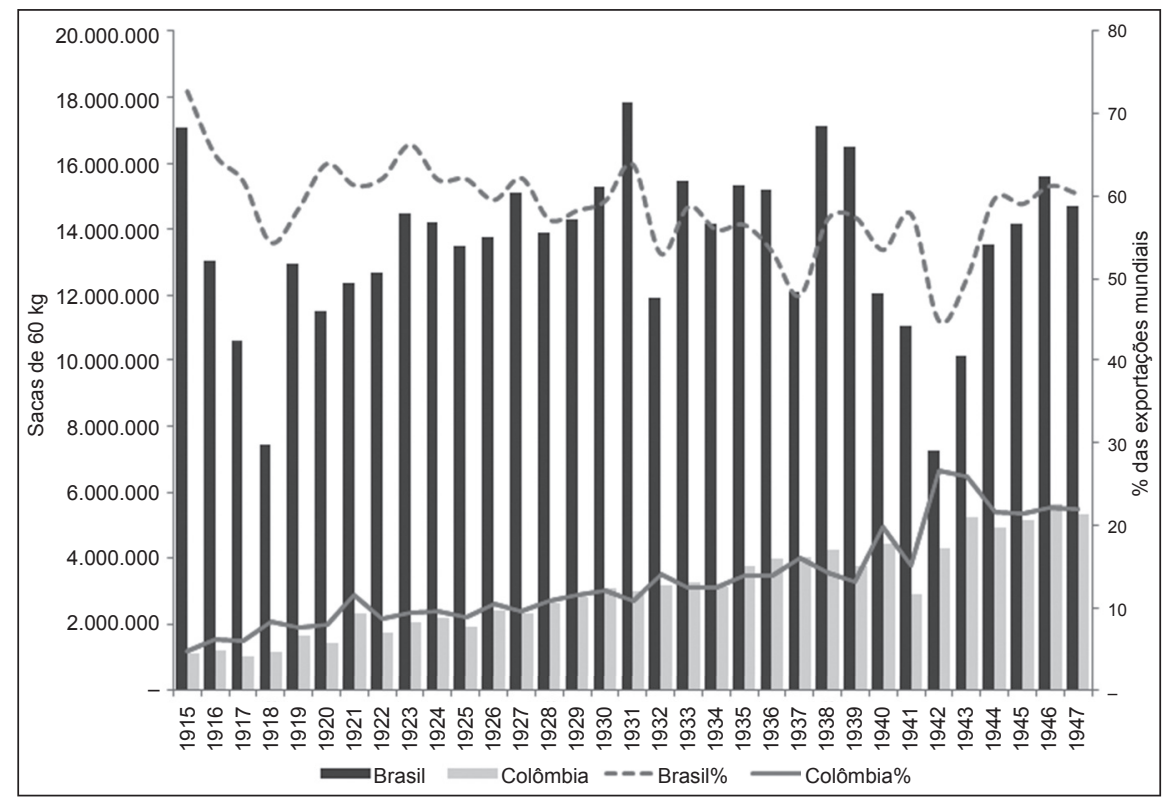

Anuário Estatístico (1948, p. 168-170). 


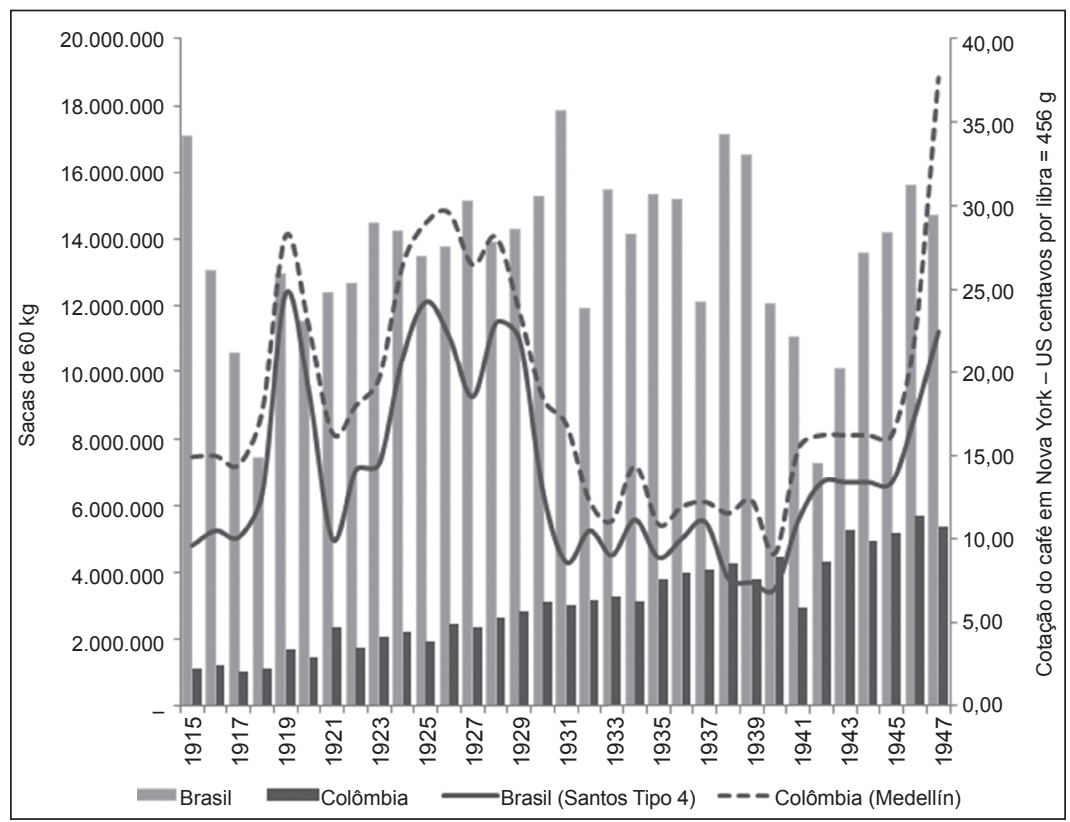

Anuário Estatístico (1948, p. 168-170).

Após os "sísmicos e hegemônicos" abalos da Primeira Guerra, em que podemos ver a reação dos preços em 1918-1919 a partir da intervenção brasileira no mercado, notamos uma tendência de expansão das exportações brasileiras e colombianas na década de 1920. Observam-se claramente os efeitos da Defesa Permanente brasileira na elevação do patamar de preço entre 1924-1929, puxando os demais produtores, no caso, a Colômbia. Tornam-se claras também, pela observação do gráfico, a depressão dos preços durante toda a década de 1930, e sua recuperação no âmbito do Acordo Interamericano do Café, e a vigorosa alta dos preços em fins da Segunda Guerra Mundial num contexto de subprodução (efeito do Departamento Nacional do Café - Brasil -, como visto acima).

Pelo lado da demanda, esta se explica quase que exclusivamente pelo mercado norte-americano. Mark Pendergrast explica o aumento do consumo de café no conjunto da sociedade estadunidense por vários fatores, um deles seria a própria Lei Seca a partir da qual muitos consumi- 
dores de estimulantes alcoólicos, que raramente bebiam café, passaram a consumi-lo com certa regularidade nas nascentes cafeterias das grandes cidades na década de 1920. Alice Foote MacDougall (Nova York) e Hills Brothers (propagados a partir da Califórnia) expandiram o hábito do luxuoso consumo de cafés colombianos e da América Central na era do jazz, enquanto a A\&P, de John Hartford, investira na venda direta aos consumidores (Pendergrast, 2002, p. 168-172).

Há também o crescente esforço de propaganda, a famosa campanha da N.W.Ayer, financiada pelo governo brasileiro e por atacadistas americanos, o filme The gift of heaven, que mostrava o cultivo e o consumo de café, sendo projetado em mais de 200 salas de cinema em todo o país, com distribuição nas escolas secundárias (Pendergrast, 2002, p. 162-163). No âmbito da ciência, o renomado Samuel C. Prescott ${ }^{18}$, do Instituto de Tecnologia de Massachusetts (MIT), foi contratado por "cafelistas" para pesquisar os efeitos do café sobre a saúde, concluindo tratar-se de "bebida digna de confiança e apreciável, reforçando as energias e melhorando a resistência". As conclusões de Prescott foram publicadas e lidas em jornais por mais de 15 milhões de pessoas (Pendergrast, 2002, p. 164). Entrementes, nenhuma dessas explicações é mais poderosa do que a crescente urbanização da vida derivada do avanço da industrialização nos Roaring Twenties: a necessidade de estimulantes para garantir a atenção necessária ao repetitivo e mecânico esforço laboral no âmbito do fordismo em jornadas de trabalho cada vez mais extensas.

No que se refere à Europa, Justus Fenner contribui ao debate indicando o papel dos comerciantes hanseáticos na popularização do consumo de café na Alemanha, desde a segunda metade do século XIX. Como estratégia para redução dos riscos, definiram a segmentação de mercado na qual o café brasileiro era visto como pertencente à cesta de consumo das classes trabalhadoras, o que aproximava os alemães de circuitos dominados pelos ingleses, ao passo que o café da Costa Rica era consumido pelas elites e pela classe média, sendo que os alemães, inclusive, privilegiavam o investimento na cafeicultura centro-americana, a despeito de suas possessões na África e na Ásia (Fenner, 2013, p. 54). A partir da atuação dos hanseáticos e do galopante processo de industria-

18 Engenheiro de alimentos e microbiologista, dedicando-se, sobretudo, a temas como segurança alimentar, ciência dos alimentos, saúde pública e indústria microbiológica. 
lização na Alemanha, o consumo de café se popularizou na Europa Central, sendo evidentemente atingido pelos desdobramentos da Primeira Guerra Mundial, mas logo retomado na República de Weimar sob o Plano Dawes e nos acordos bilaterais sob o nazismo.

\section{Produção brasileira e seus destinos}

No período em tela, em função dos desdobramentos dos esforços acima citados e da Primeira Guerra Mundial, podemos observar no gráfico abaixo o predomínio dos Estados Unidos como principal destino das exportações brasileiras. É fato que a Europa continuou sendo um destino de destaque dos embarques, verificando-se abrupta queda no contexto da debacle mundial de 1939 a 1945. Os demais importadores das sacas brasileiras respondiam por cerca de 10\% dos embarques.

Gráfico 5 - Destinos mundiais das exportações brasileiras de café (1915-1947)

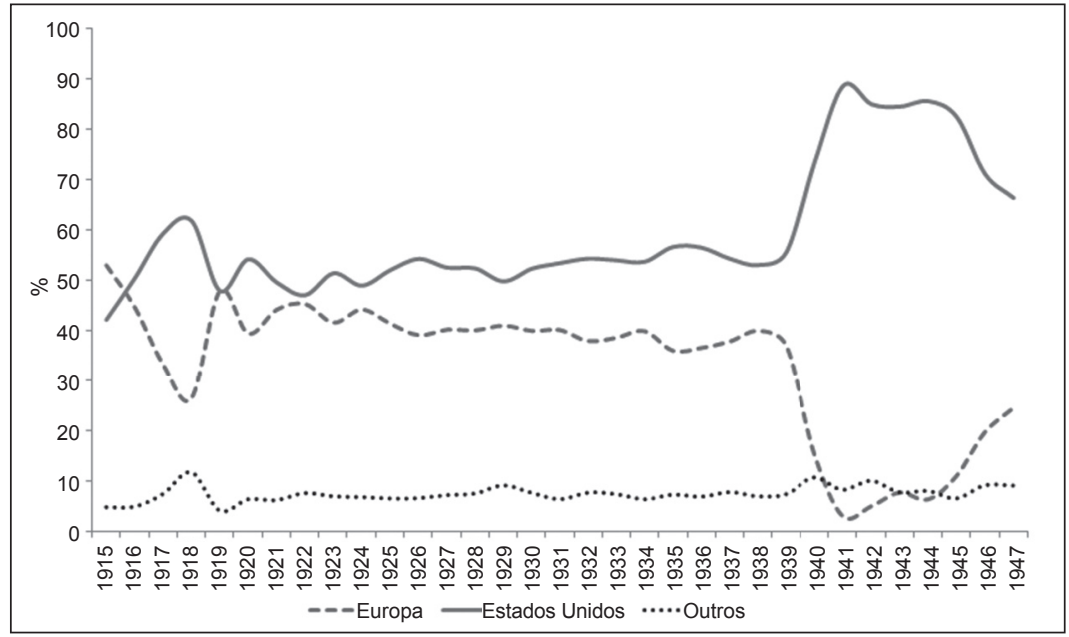

Anuário Estatístico (1948, p. 88-98).

A paulatina redução da participação europeia nas exportações brasileiras nas décadas de 1920 e 1930 está ligada às dificuldades econômicas relacionadas à Primeira Guerra Mundial e às reparações de guerra impostas em Versalhes (derrubando abruptamente as importações alemãs), 
à crise do padrão-ouro em função de fluxos de capitais desestabilizadores e correlatos desequilíbrios orçamentários e instabilidades cambiais, aos problemas de integração e retomada de crescimento dos mercados e economias europeias e aos próprios efeitos da Crise de 1929 e da Grande Depressão.Autores como Eichengreen (2000), Keynes (2002), Kindleberg (1985), McNeil (1986), Arthmar (2002) e Mazzucchelli (2009), que sob diferentes prismas analisaram o período em tela, são unânimes em afirmar que a posição americana (na economia e na política) dificultou a recuperação do velho continente ao não criar condições de maior coordenação na economia mundial, sobretudo em seus fluxos comerciais e financeiros, retardando sobremaneira o ritmo de recuperação das economias europeias. O grande diferencial de reservas em ouro, de produtividade industrial e agrícola, o protecionismo, os fluxos de capitais privados ${ }^{19}$ e o primado do mercado interno sobre o comércio internacional constituem elementos de uma postura nada favorável aos interesses europeus naquele momento:"o isolamento dos Estados Unidos em relação aos problemas mundiais no entreguerras era somente a imagem da sua inabalável segurança em continuar progredindo com base nas suas próprias forças sem a menor ameaça externa aos seus interesses nacionais" (Arthmar, 2002, p. 115).

Os rebatimentos desse contexto no mercado mundial de café podem ser vistos abaixo. Observando a mesma informação do gráfico anterior, mas agora no que se refere às sacas exportadas pelo Brasil, podemos perceber como a dinâmica mundial pela rubiácea se torna reflexa da demanda americana até sucumbir totalmente a ela em 1941, em função da Segunda Guerra e do Acordo Interamericano de Café, respondendo

19 "Não levou muito tempo para que os arquitetos do novo padrão ouro [década de 1920] concluíssem que ele não estava funcionando conforme planejado. Alguns países passaram a registrar persistentes deficit em seus balanços de pagamentos, assim perdendo suas reservas de ouro e divisas estrangeiras. Com exceção de um pequeno superavit em 1928, a Grã-Bretanha registrou um deficit generalizado em todos os anos no período de 1927 a 1931. Outros países desfrutaram de persistentes superavit e entradas de reservas. $\mathrm{O}$ balanço de pagamentos francês $[\ldots]$ registrou superavit em todos os anos no período de 1927 a 1931. Os Estados Unidos registraram superavit na maior parte da década de 1920. O mecanismo de ajuste que supostamente eliminaria os superavit e deficit e restauraria o equilíbrio nas contas internacionais parecia funcionar inadequadamente. E não era possível confiar nos fluxos de capital estabilizadores que, no passado, haviam financiado os deficit em conta corrente dos países industrializados." (Eichengreen, 2000, p. 103) 
os Estados Unidos por cerca de 90\% das exportações do maior produtor (em que pese o fato de que as exportações brasileiras tenham se reduzido em cerca de 6 milhões de sacas entre 1938, o início da guerra, e 1941). Evidentemente, trata-se de ano atípico em função da destruição de certos circuitos comerciais causados pela guerra, e aos poucos a Europa vai recuperando sua participação no mercado mundial, que se estabiliza em torno de 30\% já em inícios da década de 1950.

Gráfico 6 - Exportações brasileiras de café: Estados Unidos e mundo (1915-1947)

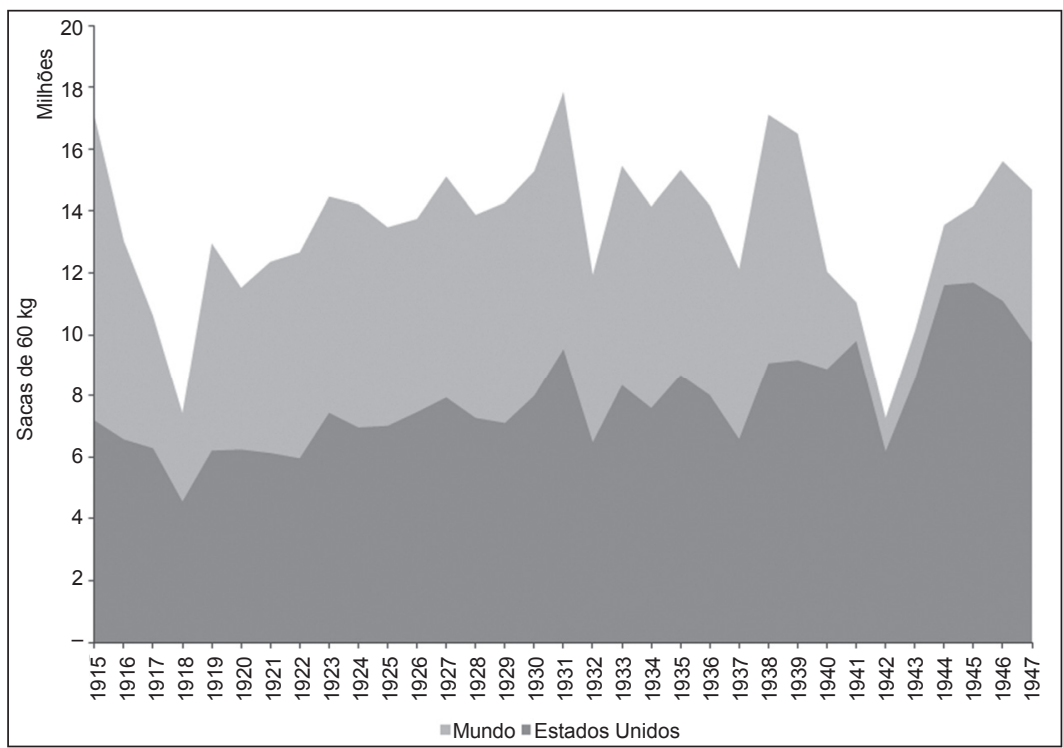

Anuário Estatístico (1948, p. 88-98).

Abaixo podemos visualizar, por países selecionados (exclusive Estados Unidos), o movimento de exportação da produção brasileira. $\mathrm{O}$ escopo era deveras superior ao colombiano, direcionado massivamente ao gigante do Norte, abrangendo praticamente todos os continentes. Chama a atenção, no Gráfico 7, a drástica redução no contexto das guerras (no que se refere aos países europeus). A preponderância da França como destino das exportações brasileiras no velho continente é notória, contudo o mercado alemão, restaurado a partir do Plano Dawes em 1924, recupera a importância verificada no cenário anterior à Primeira Guerra, 
momento auge das operações da Theodor Wille \& Co. nos portos de Hamburgo e Bremen. Itália, Holanda, Bélgica-Luxemburgo compunham também mercados significativos, contudo revelando trajetórias erráticas em função das mazelas que afligiam a Europa. Interessante notar, novamente, a abrupta redução nas importações daquele continente a partir de 1940, ou que, em função do Acordo Interamericano do Café, as sacas estivessem sendo reexportadas a partir de atacadistas americanos, dada a desarticulação comercial verificada.

Gráfico 7 - Exportações brasileiras de café: países selecionados (1915-1947)

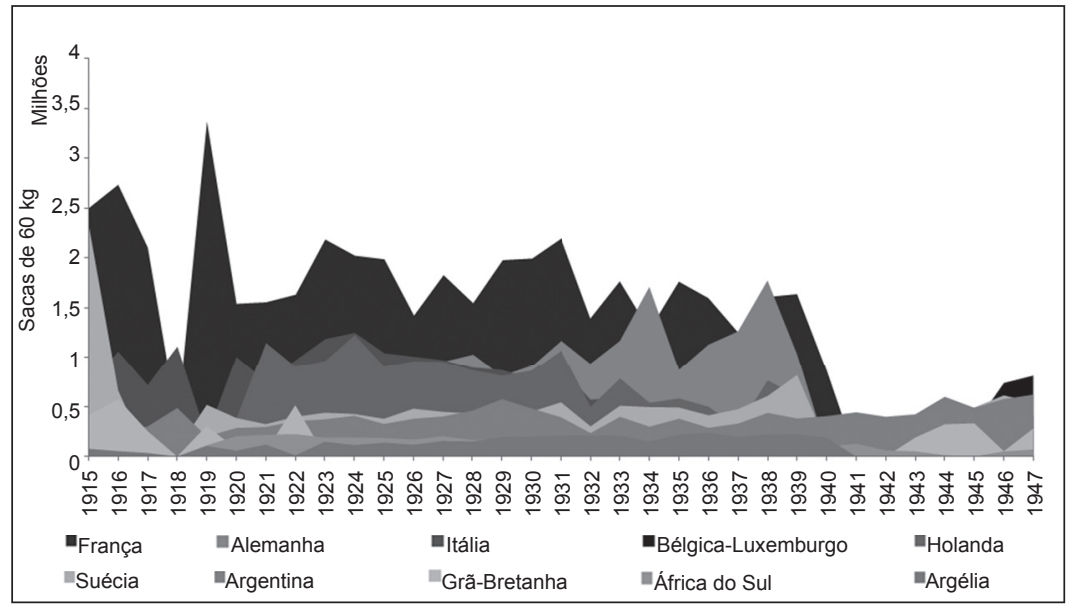

Anuário Estatístico (1948, p. 88-98).

Percebemos, acima, claramente a derrocada das importações de café brasileiro na Primeira Guerra, o pico em 1919 para a recomposição dos estoques do Havre (França) e a retomada alemã, intensificada na década de 1930 com os acordos bilaterais. Esses países, ao lado da Itália, da Holanda e dos Estados Unidos (evidentemente), eram os maiores destinos da produção brasileira. Interessante notar que, embora a variação em termos de sacas importadas seja considerável, a coordenação dos preços é notável a partir das defesas brasileiras. Temos abaixo um gráfico indicando em libras, a preços constantes de 1919, e os valores das sacas de $60 \mathrm{~kg}$ (Santos Tipo 4) exportadas pelo Brasil. Ainda que flutuantes em função da demanda e das condições econômicas e cambiais, mas, sobretudo, dos estoques, leia-se intervenções governamentais, os preços indicam 
grande coordenação entre os diferentes importadores, o que nos permite inferir com certa segurança que a posição "quase" monopólica do país e seu peso no mercado serviam como parâmetro para a formação de preços em geral (ver Gráfico 4). O ponto da argumentação é que os demais produtores não alcançavam volume compatível com a demanda mundial, e que o café brasileiro era fundamental na composição de blends, sendo um típico produto de consumo de massas. Sabedor de suas posições, os financistas internacionais em convênio com o governo brasileiro empreenderam uma série de intervenções no mercado, que levaram a esse elevado nível de coordenação.

Gráfico 8 - Libra por saca de $60 \mathrm{~kg}$ (Santos Tipo 4)

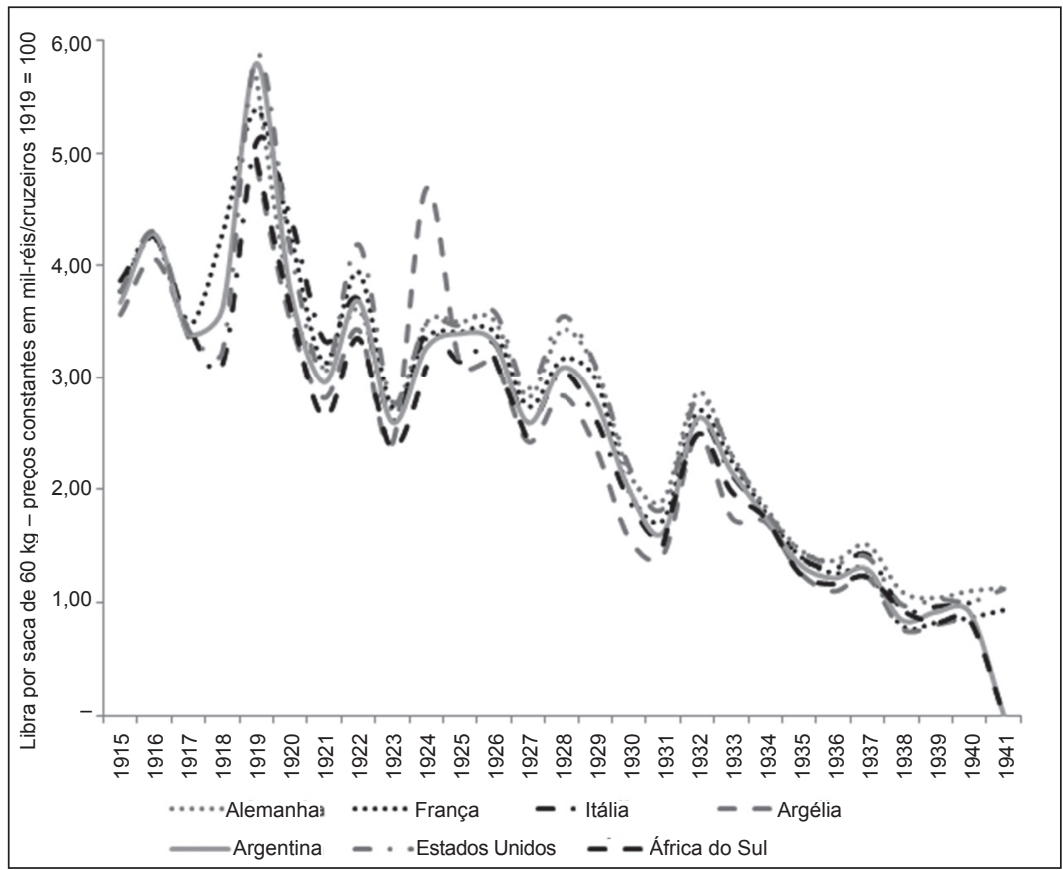

Anuário Estatístico (1948, p. 88-98).

Exemplificando o que já fora dito anteriormente, temos abaixo um gráfico pontuando os momentos das intervenções brasileiras no mercado cafeeiro. A valorização de 1917-1918 encontra resultado fantástico a partir da junção de fatores como a geada de 1918 e o iminente final da 


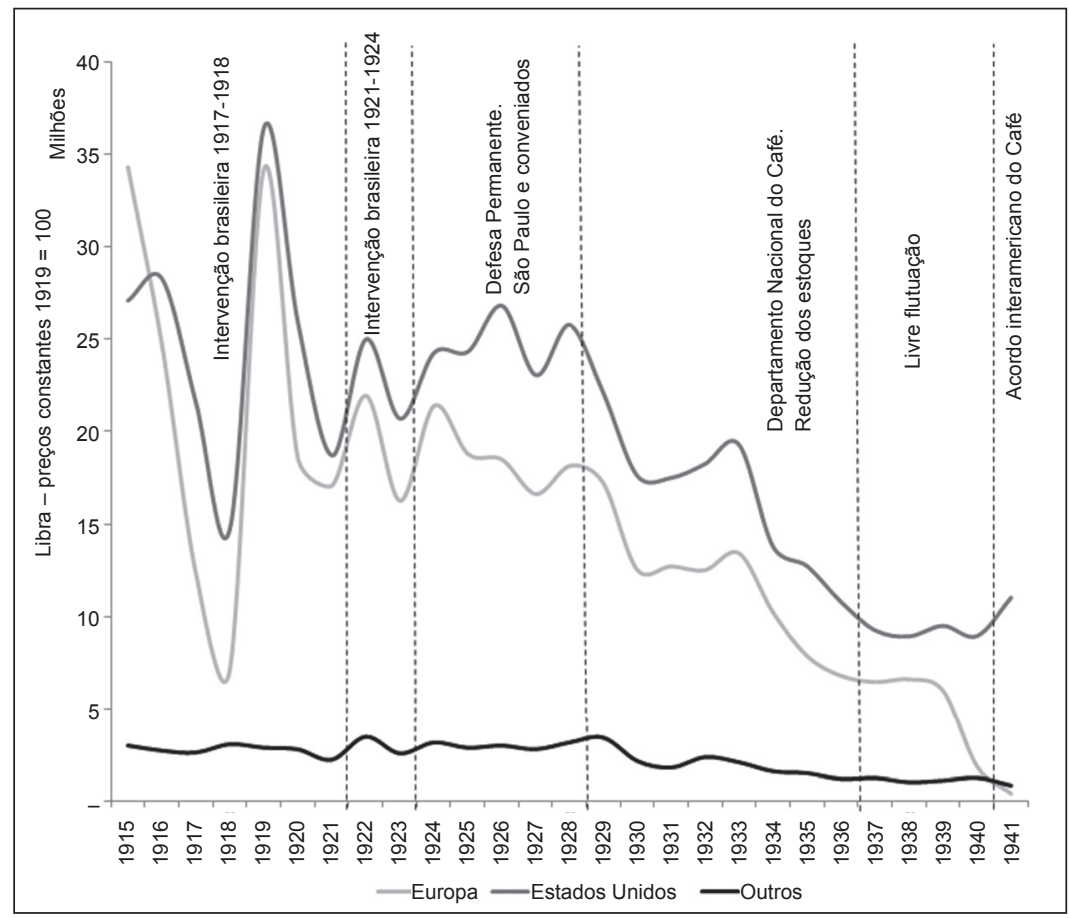

Fonte: Elaboração própria a partir do Anuário Estatístico (1948, p. 88-98).

guerra; já a intervenção de 1921-1924 também pode ser considerada exitosa, dada as grandes safras verificadas e o (embora curto) elevado grau de recessão da economia americana em 1921, bem como a dificuldade de reconstrução do comércio europeu.A Defesa Permanente, inaugurada em 1924, também sustenta os preços em patamar bem mais elevado do que teria ocorrido caso não tivesse sido implementada, dados os crescentes estoques advindos do avanço da fronteira agrícola em São Paulo e a correlata pressão baixista. A partir da Crise de 1929 e seus desencadeamentos que redundaram em uma grande depressão, os preços não mais retornaram aos níveis anteriores, embora o quantum exportado não tenha necessariamente se reduzido (ver Gráfico 4). Nem mesmo o esforço do Departamento Nacional do Café, para a eliminação dos estoques indesejados, fora suficiente para a manutenção dos preços em moeda forte, situação que pioraria a partir de 1937, quando o governo brasileiro deixou de intervir no mercado buscando um acordo com os demais 
produtores mundiais. Em certo sentido, a estratégia forçou um acordo entre os produtores e os Estados Unidos, que capitanearam o Acordo Interamericano do Café de 1941 até 1946.

\section{Disputas interestatais e mercado cafeeiro}

Como vimos acima, as intervenções brasileiras ditavam a formação dos preços na economia mundial. Em que pese o fato de, do lado da oferta, termos o Brasil respondendo de $50 \%$ a $60 \%$ da produção mundial e, do lado da demanda, os Estados Unidos respondendo por cerca de $60 \%$ a $70 \%$ do consumo mundial no período em tela, o comércio mundial de café esteve distante de um mero arranjo entre ambos, o que só viria a acontecer em 1941.

Temos abaixo uma figura-síntese da argumentação que desenvolveremos nestas notas conclusivas:

Figura 1 - Eixos de intervenção no mercado cafeeiro (1915-1947)

\begin{tabular}{|c|c|c|c|c|c|}
\hline \multicolumn{2}{|c|}{ Estados Unidos } & \multicolumn{2}{|c|}{$\begin{array}{l}\text { Inglaterra, } \\
\text { Alemanha }\end{array}$} & \multicolumn{2}{|c|}{ França, Bélgica } \\
\hline 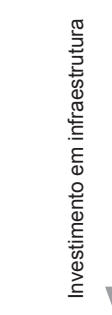 & 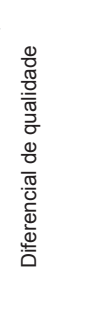 & 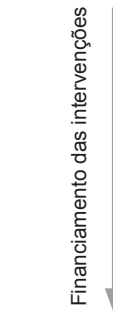 & 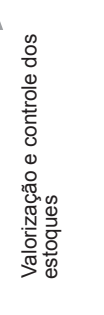 & 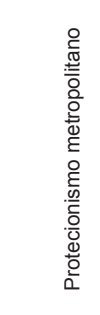 & 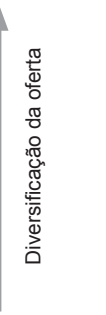 \\
\hline \multicolumn{2}{|c|}{$\begin{array}{c}\text { Colômbia, América Central } \\
\text { (exportação média anual } \\
\text { de } 7,5 \text { milhões de sacas, } \\
1915-1947 \text { ) }\end{array}$} & \multicolumn{2}{|c|}{$\begin{array}{c}\text { Brasil } \\
\text { (exportação média anual } \\
\text { de 13,9 milhões de sacas, } \\
1915-1947 \text { ) }\end{array}$} & \multicolumn{2}{|c|}{$\begin{array}{c}\text { África colonial } \\
\text { (exportação média anual } \\
\text { de } 1 \text { milhão de sacas, } \\
\text { 1915-1943) }\end{array}$} \\
\hline
\end{tabular}

Fonte: elaboração própria.

Tratando do eixo central da figura, o financiamento inglês, assim como a infraestrutura logística e de transportes alemã ${ }^{20}$ (suas ferrovias com conexões continentais, ao lado de companhias marítimas de grande

20 A Alemanha é até hoje o maior exportador mundial de cafés verdes. 
capacidade, como a Hamburg Sud e a dinamarquesa Maersk, por exemplo), pelo menos enquanto puderam funcionar a contento, entre 1924 e 1938, proporcionavam dois elementos importantes para a defesa brasileira: (1) recursos para o financiamento dos estoques, bem como a sua infraestrutura (armazéns e ferrovias); (2) controle sobre a colocação dos cafés no continente europeu, particularmente após os acordos bilaterais com o III Reich. Em especial os capitais britânicos, representados pelo banco Lazard Brothers em seu empréstimo ao estado de São Paulo, que deu sustentação à Defesa Permanente, agiam diretamente na formação dos preços ao segurar a produção nos armazéns reguladores. Como é destacado na literatura especializada sobre o tema (Delfim Netto, 1979), essa intervenção não estabeleceu controles efetivos sobre a formação de novas lavouras, sendo cada vez maior a necessidade de captação de novos empréstimos para a sustentação dos preços, em geral, britânicos ${ }^{21}$.Assim, forjava-se uma aliança hierarquizada entre a burguesia cafeeira brasileira, notadamente paulista, mas não somente, e a banca inglesa, dado que a elevação do preço das sacas garantia os meios de pagamento internacionais. O governo federal mantinha desde a Missão Montagu (1924) o compromisso com a manutenção da conversibilidade (Fritsch, 1980), reforçando ainda mais as garantias para a banca inglesa e alemã.

A estratégia penalizava o consumidor final norte-americano, elevando o preço do café a patamares claramente artificiais. A resposta americana parece ter sido a de promover ofertantes alternativos ao Brasil, sobretudo a Colômbia e países da América Central (eixo à esquerda na figura), com esforços significativos na melhoria de infraestrutura de transporte desses países ${ }^{22}$, sendo o país sul-americano um caso de destaque, como também grande esforço de publicidade, propaganda e pesquisa para a "construção" da superior qualidade desses grãos, aumentando a pressão baixista sobre a produção brasileira. Essa estratégia foi amadurecendo paulatinamente, após a Guerra dos Mil Dias e o Convênio de Taubaté, encontrando seu ápice na década de 1920 como resposta à defesa permanente dos estados produtores brasileiros. Como vimos acima, o aporte

21 Mas não somente. O estado do Espírito Santo, por exemplo, captou recursos no Banco Ítalo-Belga para a implementação do Serviço de Defesa do Café daquele estado, em 1927.

22 "Os países exportadores de capitais partilham (no sentido figurado da palavra) o mundo entre si." (Lenin, 1979, p. 65) 
de recursos norte-americano na Colômbia foi considerável nesse período, dando vazão à exportação de capitais daquele país. É evidente que a Colômbia e a América Central não conseguiam isoladamente abastecer a totalidade do mercado americano, sobretudo o ordinário chão de fábrica; por isso, durante todo o período, os Estados Unidos mostram-se dependentes da produção brasileira financiada pela Inglaterra.

Já a estratégia franco-belga (à direita na figura) valeu-se de diferenciados artifícios para "quebrar" a valorização brasileira. Esses países, dois dos principais importadores mundiais, buscaram intensificar os seus respectivos sistemas coloniais na África ${ }^{23}$. A produção cafeeira nesse continente fora crescente na primeira metade do século XX, sobretudo na década de 1930, no âmbito dos acordos bilaterais nascidos das dificuldades de pagamentos internacionais derivadas do estilhaçamento do padrão-ouro. A Etiópia e a Eritreia, outrora colônias italianas, moveram-se como países independentes; a plêiade francesa era composta por Madagascar, pela África Ocidental Francesa e pela África Equatorial Francesa, assim como a belga era composta pelo Congo. Angola e São Tomé e Príncipe, embora colônias portuguesas, sofriam poucas ações metropolitanas, mesmo sendo produtores listados no continente, e a própria Inglaterra, na década de 1930, fomentou a produção na África Oriental Britânica (Quênia), numa clara manobra da Commonwealth. Acima, o Gráfico 2 atesta o crescimento da produção africana, atingindo 2,5 milhões de sacas exportadas em 1938. A estratégia era dotar Havre (principal porto cafeeiro da França) de oferta alternativa àquela oriunda do Brasil e da América Latina, de elevados preços em função das intervenções e da propaganda. Contudo, parece ter sido insuficiente, em função do baixo volume produzido e pelo fato de que as maiores potencialidades do continente africano estavam nos cafés da família Robusta (também conhecida por Conilon ${ }^{24}$ ), até então não muito bem difundidas.

23 "O capital financeiro acrescentou aos numerosos 'velhos' motivos da política colonial o da luta pelas fontes de matérias-primas, pela exportação de capitais, pelas 'zonas de influência' - isto é, pelas zonas de vantajosas transações, de concessões, de lucros de monopólio, etc. - e, finalmente, pelo território econômico em geral.” (Lenin, 1979, p. 123)

24 O Coffea canefhora tem origem no Congo, possui alto teor de cafeína e é utilizado em blends juntamente com o Coffea arábica, oriundo da Etiópia. O continente africano possui em Uganda e na Costa do Marfim os seus maiores produtores, e 40\% da atual produção africana hoje é dessa família. O Brasil é o maior produtor de 
Assim, o mercado cafeeiro no período em tela apresentava disputas entre três eixos, capitaneados entre Estados Unidos, França e Inglaterra, cuja haute finance constituía o coração do sistema, sendo no Brasil fundamental nessa estratégia. Certamente os diferenciais de preço auferidos pelas intervenções favoreceram sobremaneira os interesses daqueles grupos. Pelo lado norte-americano, estava em jogo, para além da disputa com a primazia britânica nesse ramo, a possibilidade de exportação de capitais para as periferias americanas: Colômbia, Costa Rica, Cuba, Guatemala, México,Venezuela, Nicarágua, Honduras, República Dominicana e demais produtores americanos. Aos franceses e belgas, o embate com a dominância anglo-germânica se dava pelo reavivamento de seus Impérios coloniais. Contudo, as disputas soçobraram com a Segunda Guerra Mundial, momento no qual ingleses, alemães, franceses e belgas capitularam nesse ramo a partir do Acordo Interamericano do Café em 1941, realizando o desiderato americano e sua dominância imperialista.

\section{Considerações finais}

As teorias vinculadas às Global Commodity Chains contribuíram à compreensão dos circuitos mercantis e lançaram luz sobre aspectos transdisciplinares ao se debruçarem sobre especificidades regionais, padrões de consumo, cultura e desdobramentos, limites e possibilidades ativadas pela atividade nuclear de exportação. Também abrem a janela de compreensão a partir de novas instituições criadas para a manutenção, a estabilidade e o desenvolvimento de cadeias de mercadorias de longo prazo.

Buscando trabalhar nessa perspectiva e avançar, ambicionamos neste artigo contribuir para o debate resgatando as concepções de Arrighi acerca da construção histórica do capitalismo, trazendo para primeiro plano as disputas hegemônicas interestatais e suas determinantes sobre o mercado cafeeiro. O Brasil, evidentemente, como maior produtor, esteve no centro de qualquer estratégia, e sua vinculação de longa duração com o capital britânico dotou os operadores dos circuitos do café

café Conilon do mundo. A expansão do Robusta tem se expandido em função do aumento da temperatura global, que afeta mais diretamente o café Arábica. 
desse país de algumas vantagens concorrenciais em relação aos demais: enquanto vigorou o padrão-ouro e sua capacidade de enquadramento das periferias como principal fonte de crédito, a dominância inglesa fez-se presente na definição das políticas econômicas encampadas pelo maior ofertante. A Defesa Permanente definida em 1924, com a Missão Montagu e o explícito compromisso de Arthur Bernardes com a conversibilidade da moeda e o equilíbrio fiscal, constituem exemplo dessa dominância, elevando o preço do café, naquela ocasião, a patamares superiores à média histórica, mesmo num contexto de crescente superprodução. A participação alemã também é relevante, considerando sua estrutura de reexportação, formação de blends e de transporte pelo velho continente.

Contudo, à parte desse eixo de alianças, encontravam-se os Estados Unidos, detentores do maior e mais promissor mercado consumidor de café, em função do advento da industrialização, da urbanização e do notável esforço propagandístico. Em que pese a participação de E. Sielcken no Convênio de Taubaté, a presença norte-americana no financiamento da atividade cafeeira no Brasil era reduzida quando comparada à da Inglaterra, dado que não verificamos nenhum aporte americano às intervenções brasileiras. Como resposta, verifica-se a promoção de produtores alternativos, viabilizados na esteira da valorização brasileira, dotados de patamar de qualidade dos grãos superior ao brasileiro, impondo contínua pressão baixista. O esforço de propaganda e a correlata construção social da qualidade dos cafés colombianos impunham dificuldades ao Brasil na medida em que necessitava reter um volume cada vez maior de sacas de grãos ordinários, com rebatimentos em crescente demanda por crédito externo.Ademais, W.Wilson e H. Hoover já haviam criticado publicamente a intervenção, e a promotoria pública já em 1912 havia determinado que Sielcken jogasse no mercado todos os estoques nova-iorquinos em seu poder, em benefício do consumidor americano, visto que a política brasileira o impunha fardo adicional.

Os franceses e belgas, sobretudo após a Crise de 1929, buscaram reavivar suas possessões coloniais alcançando certo sucesso, porém, em patamar ainda insuficiente para o abastecimento do Havre.

A Segunda Guerra Mundial liquidou definitivamente a dominância britânica sobre a produção cafeeira mundial, que viria a ser hierarquizada pelos Estados Unidos já em 1941 com o Acordo Interamericano do Café, assinado em Washington (DC) pelo anfitrião e mais 13 países produtores 
(incluindo o Brasil).Em termos globais, o maior esforço de coordenação do mercado cafeeiro só viria a acontecer em 1959, com o Acordo Internacional do Café, incorporando produtores africanos. $\mathrm{O}$ acordo, que evolui para um Convênio Internacional em 1962, chegou a ter 67 membros: 42 exportadores e 25 importadores, que representavam 99,8\% das exportações mundiais de café e 96,2\% das importações (Lafer, 1973). A dominância americana fora implacável nesse contexto, finalizando um grande ciclo de disputas hegemônicas e marcando a consolidação do quarto Ciclo Sistêmico de Acumulação (CSA), nos termos de Arrighi (1996), aqui observado pela ótica do mercado cafeeiro.

\section{Referências bibliográficas}

ANUÁRIO Estatístico 1948. Superintendência dos Serviços do Café. Secretaria da Fazenda do Estado de São Paulo, 1948.

ARRIGHI, Giovanni. O longo século XX. Poder, dinheiro e as origens do nosso tempo. Rio de Janeiro: Contraponto/UNESP, 1996.

ARTHMAR, Rogério. Os Estados Unidos e a economia mundial no pós-Primeira Guerra. Estudos Históricos. Rio de Janeiro, n. 29, p. 97-117, 2002.

AURELIANO, Liana. No limiar da industrialização. 2. ed. Campinas: IE-UNICAMP, 1999.

BACHA, E.; GREENHILL, R. 150 anos de café. Rio de Janeiro: Marcellino Martins \& E. Johnston Exportadores Ltda., 1992.

CLARENCE-SMITH, W. G.; TOPIK, S. The global coffee economy in Africa, Asia and Latin America, 1500-1989. New York: Cambridge University Press, 2003.

CPDOC. Café, mimeo., s.d. Disponível em <http://cpdoc.fgv.br/sites/default/files/ verbetes/primeira-republica/CAF\%C3\%89.pdf>. Acesso em 8/2/2017.

DELFIM NETTO, Antônio. O problema do café no Brasil. Rio de Janeiro: Fundação Getúlio Vargas/Ministério da Agricultura/SUPLAN, 1979.

EICHENGREEN, Barry. A globalização do capital. Uma história do sistema monetário internacional. São Paulo: Editora 34, 2000.

FALEIROS, Rogério Naques. Fronteiras do café: fazendeiros e "colonos" no interior paulista (1917-1937). Bauru/São Paulo: EDUSC/FAPESP, 2010.

FALEIROS, Rogério Naques; NUNES, Ivanil. Estrutura e funcionamento do Serviço de Defesa do Café no Espírito Santo entre 1927 e 1930. Sistemas de transporte e formações econômicas regionais. Brasil e Argentina.V. 1.Vitória: EDUFES, 2016.

FENNER, J. Configurando la cadena de café: casas mercantiles alemanas y consumo de café guatemalteco en Alemania, 1889-1929. América Latina en la Historia Económica. Norteamérica, v. 20, n. 3, 26 ago. 2013. Disponível em <http://alhe.mora.edu.mx/ index.php/ALHE/issue/view/56>. Acesso em 3/2/2019. 
FRITSCH, Winston. 1924. Pesquisa e Planejamento Econômico. Rio de Janeiro, v. 10 (3), p. 713-774, dez. 1980.

FRITSCH,Winston. External constraints on economic policy in Brazil, 1889-1930. London: Mcmillan, 1988.

GRANER, E.A.; GODOY JR., C. (coords.). Manual do cafeicultor. São Paulo: EDUSP/ Melhoramentos, 1967 (colab. A. Carvalho et al.).

HYNES, W.; JACKS, D. S.; O'ROURKE, K. H. Commodity market disintegration in the interwar period. European Review of Economic History. Oxford University Press, v. 16 (2), p. 119-143, 2012.

KENWOOD, A. G.; LOUGHEED, A. L. Historia del desarrollo económico internacional. Madrid: Istmo, 1995.

KEYNES, John M. As consequências econômicas da paz. São Paulo: Imprensa Oficial do Estado/Instituto de Pesquisa de Relações Internacionais, 2002.

KINDLEBERG, Charles P. La crisis económica, 1929-1939. Barcelona: Crítica, 1985.

LAFER, Celso. O Convênio Internacional do Café. Revista da Faculdade de Direito da Universidade de São Paulo. São Paulo, v. 68, n. 2, p. 285-340, 1973. Disponível em <http://www.revistas.usp.br/rfdusp/article/view/66676/69286>. Acesso em $7 / 2 / 2019$.

LENIN,V. Imperialismo, fase superior do capitalismo. São Paulo: Global, 1979.

MAZZUCCHELLI, F. Os anos de chumbo: economia e política internacional no entreguerras. São Paulo/Campinas: UNESP/FACAMP, 2009.

McNEIL, William C. American money and the Weimar Republic. Economics and politics on the eve of the Great Depression. New York: Columbia University Press, 1986.

OCAMPO, José Antônio. O mercado mundial de café e o surgimento da Colômbia como um país cafeicultor. Revista Brasileira de Economia. Rio de Janeiro, v. 37, n. 4, p. 449-482, 1983.

PELÁEZ, Carlos. Análise econômica do programa brasileiro de sustentação do café 1906-1945:Teoria, política e medição. Revista Brasileira de Economia. Rio de Janeiro, v. 25, n. 4, p. 5-212, out.-dez. 1971.

PENDER GRAST, Mark. El café. Historia de la semilla que cambió el mundo. Buenos Aires: Javier Vergara Editor, 2002.

PÉREZTORO, José Alberto. Economía cafetera y desarollo económico en Colombia. Bogotá: Universidad de Bogotá Jorge Tadeo Lozano, 2013.

PINTO, Joaquín. Carlos Marichal, Steven Topik y Zephyr Frank (coords.), De la plata a la cocaína. Cinco siglos de historia económica de América Latina, 1500-2000. El Colegio de México/Fondo de Cultura Económica, México, 2017, 526 pp. América Latina en la Historia Económica. México, 2018.

PIRES, A. Minas Gerais e a cadeia global da "commodity" cafeeira - 1850/1930. Revista Brasileira de Gestão e Desenvolvimento Regional, v. 3, n. 2, p. 139-194, maio-ago. 2007.

SAES, Maria Sylvia Machionne. A racionalidade econômica da regulamentação no mercado brasileiro de café. São Paulo: Annablume/FAPESP, 1997. 
TOPIK, S. The integration of the world coffee market. In: CLARENCE-SMITH, W. G.; TOPIK, S. The global coffee economy in Africa, Asia and Latin America, 1500-1989. Cambridge (UK)/New York: Cambridge University Press, 2003.

TOPIK, S.; MARICHAL, C.; FRANK, Z. Commodity chains in theory and in Latin American history. From silver to cocaine: Latin American commodity chains and the building of the world economy, 1500-2000. Durham/London: Duke University Press, 2006, p. 1-24.

TOPIK, S.; SAMPER, M. The Latin American coffee commodity chain: Brazil and Costa Rica. In:TOPIK, S.; MARICHAL, C.; FRANK, Z. From silver to cocaine: Latin American commodity chains and the building of the world economy, 1500-2000. Durham/London: Duke University Press, 2006, p. 118-146.

TOSI, Pedro Geraldo Saadi; FALEIROS, Rogério Naques. O café no Brasil: produção e mercado mundial na primeira metade do século XX. ANAIS DO XII CON-

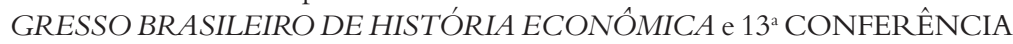
INTERNACIONAL DE HISTÓRIA DE EMPRESAS. Niterói: UFF, 2017. Disponível em <http://www.abphe.org.br/uploads/ABPHE\%202017/41\%20 O\%20Caf\%C3\%A9\%20no\%20Brasil\%20Produ\%C3\%A7\%C3\%A3o\%20e\%20 Mercado\%20Mundial\%20na\%20primeira\%20metade\%20do\%20s\%C3\%A9culo\%20 XX.pdf>. Acesso em 27/1/2019.

VILLELA, Aníbal V.; SUZIGAN, Wilson. Política do governo e crescimento da economia brasileira, 1889-1945. 3. ed. Brasília: IPEA, 2001. 